\title{
Efficacy of Ampelomyces spp. against powdery mildew disease of rose caused by Podosphaera pannosa
}

\section{Wanasiri $\mathbf{N}^{1}$, McGovern $\mathbf{R} \mathbf{J}^{1}$, Cheewangkoon $\mathbf{R}^{1}$, Kongtrakual $\mathbf{P}^{2}$ and To-Anun $\mathbf{C}^{\mathbf{1}^{*}}$}

\footnotetext{
${ }^{1}$ Department of Entomology and Plant Pathology, Faculty of Agriculture, Chiang Mai University, Chiang Mai, Thailand.

${ }^{2}$ Department of Plant Production Technology, Faculty of Agricultural Technology, King Mongkut's Institute of Technology Ladkrabang.
}

Wanasiri N, McGovern RJ, Cheewangkoon R, Kongtrakual P, To-Anun C 2020 - Efficacy of Ampelomyces spp. against powdery mildew disease of rose caused by Podosphaera pannosa. Plant Pathology \& Quarantine 10(1), 21-27, Doi 10.5943/ppq/10/1/3

\begin{abstract}
The fungus Ampelomyces spp., a hyperparasite of powdery mildews, was isolated from flowering plants Zinnia elegans, Ageratum conyzoides, Hydrangea sp., and Dahlia spp. The morphological characteristics were observed using light and scanning electron microscopes. Pycnidia variable in shape (ovoid and ellipsoid) and conidia measuring 10.5 to $13.5 \mu \mathrm{m}$ in length $\times$ 2.5 to $3.0 \mu \mathrm{m}$ in width were detected. Four isolates of Ampelomyces spp. were obtained, AMP1-Ze, AMP2-Ac, AMP3-Hg and AMP4-D1, to study their ability to inhibit conidial germination on onion cell tissue of the fungus Podosphaera pannosa which causes rose powdery mildew. The biocompounds produced by these mycoparasites had $\mathrm{LC}_{50}$ values between 91.20-190.55 ppm. The most effective biocompound was produced by the Ampelomyces-from Ageratum conyzoides (AMP2-Ac) and it was compared to a conventional fungicide (carbendazim 10cc/20L) and control (non-treated). This biocompound reduced the severity of powdery mildew disease by $45.33 \%$ in greenhouse experiments.
\end{abstract}

Key words - Antagonistic fungi - biological control - hyperparasite - Podosphaera pannosa

\section{Introduction}

Powdery mildew of rose caused by Podosphaera pannosa, is an obligate biotrophic parasite that results inepidemics in greenhouses and landscapes at temperatures of $21-25^{\circ} \mathrm{C}$ and low humidity (Paulitz \& Bélanger 2001). This disease is severe on susceptible rose cultivars in Chiang Mai province, Thailand. The conidiophores of $P$. pannosa produce apical conidia which contain fibrosin bodies (Cook \& Braun 2009). Conidia and conidiophores can be spread by wind, and possibly by insects. Infections appear on young aerial parts of plants covering them with whitish colonies. Infected plants become distorted and have reduced production (Carlo et al. 1997). Using fungicides for control of rose powdery mildew disease has increased the level of applied chemicals and production costs. In addition, chemical fungicides can be phytotoxic and disrupt the antagonistic microbial activity of non-target microorganisms. 
Alternative methods for control of powdery mildew including the use of biological control agents (BCAs) are promising. Mycoparasites belonging to the genus Ampelomyces have been found on a wide host range of more than 64 species of powdery mildew (Dario et al. 2009). They have been most effective against powdery mildew fungi in the Erysiphaceae such as Erysiphe cichoracearum, Uncinula necator, Podosphaera leucotricha, and P. pannosa which causes rose powdery mildew (Puzanova 1991). The infection process of powdery mildew by Ampelomyces conidia and hyphae occurs by germ tubes which penetrate into host cells. Pycnidia are formed within hyphae and vary in shape depending on host fungal structure. Moreover, Ampelomyces spp. produce toxic metabolites and can be mass produced in artificial liquid media. Extracts of Ampelomyces spp. isolated from Urospermum picroides contained a new pyrone and sulfated anthraquinones. However, fungal growth rate was slow a few $\mathrm{mm}$ in solid culture and not feasible for commercial mass production in this manner (Dario et al. 2017). Although conidia of $A$. quisqualis isolated from Podosphaera leucotricha can germinate on water agarose medium, conidia germination decreased as conidial concentration increased at 8, 10, 20 and $34 \times 10^{6}$ spores $\mu 1^{-1}$. In addition, solid media contain nutrients that may stimulate growth of microbial contaminants (Gu \& Ko 1997). Ampelomyces quisqualis is of interest for commercial development because of its ability to control powdery mildew. Mixing A. quisqualis with paraffin, mineral oils or an additive (pinolene) made it more effective in controlling strawberry powdery mildew, a biological control strategy that can reduce conventional chemical fungicide residues (Ilaria et al. 2008). Furthermore, 2 bioactive metabolites from Ampelomyces spp. isolated from Urospermum picroides such as pyrone and sulfated anthraquinones were detected after growth in liquid or solid media. In addition, the metabolites 3-O-methylalaternin and altersolanol A showed effectiveness against the Grampositive bacterium, Staphylococcus aureus which causes human disease (Amal et al. 2008).

Therefore, the objective of this study was screening of Ampelomyces spp. to assess their efficacy as biocontrol agents against powdery mildew of rose.

\section{Materials \& Methods}

\section{Isolates and morphology}

\section{Collection and isolation of Ampelomyces spp.}

Ampelomyces spp. were isolated from four species of powdery mildew host plants: Zinnia elegans (Zinnia), Ageratum conyzoides (Chick weed), Hydrangea spp. (Hydrangea) and Dahlia spp. (Dahlia) which presented as brownish colonies on leaves. The samples were collected during November 2018- February 2019 from Chiang Mai and Chiang Rai province, Thailand (Table 1).

\section{Morphology observation by light and scanning electron microscopy}

Ampelomyces spp. were stripped off leaves by clear adhesive tap then pressed on glass slides following Cook et al. (1997) and To-anun \& Takamatsu (2007) to investigate pycnidia shape and size by light microscopy using a $40 \mathrm{X}$ objective with a phase contrast lens. The colonies of Ampelomyces sp. on leaves were cut and fixed with FAA solution (ethanol 45\%, v/v; acetic acid $6 \%$, v/v; formaldehyde 5\%, v/v and SDW 44\%) following Pathan \& Gaskin (2010) for observation of hyperparasitism by scanning electron microscopy (SEM) (JEOL 5410, Tokyo, Japan) (Fig. 1).

\section{Effect of Ampelomyces sp. on spore germination of powdery mildew}

All isolations of Ampelomyces spp. were done from leaf surfaces which were sterilized with $70 \% \mathrm{EtOH}$ for 1 min and rinsed with sterile water. Pycnidia were then transfered for mass growth production in Wickerham liquid medium ( $3 \mathrm{~g}$ yeast extract, $3 \mathrm{~g}$ malt extract, $5 \mathrm{~g}$ peptone, $10 \mathrm{~g}$ glucose, with addition of up to $1,000 \mathrm{ml}$ of distilled water, $\mathrm{pH}$ adjusted to 7.2-7.4) following Amal et al. (2008), and incubated $25^{\circ} \mathrm{C}(\mathrm{Gu} 1998)$, on a shaker $220 \mathrm{rpm}$ for $45 \mathrm{~d}$.

Four isolates of Ampelomyces spp., AMP1-Ze, AMP2-Ac, AMP3-Hg, AMP4-D1 were massproduced in the liquid medium, on liquid medium. The biocompounds were extracted with ethanol 
three times then evaporated and tested for conidial inhibition (LC50) on onion tissue using the methods of Hirata (1942) at concentrations of 0, 10, 50, 100, 500 and 1,000 ppm $48 \mathrm{hr}$. after treatment (4 treatments and 5 replications) (Table 2$)$.

\section{Greenhouse experiments}

\section{Effect of a biocompound on $P$. pannosa powdery mildew severity}

All treatments were applied weekly for $4 \mathrm{wk}$ and disease was estimated in the last week. A randomized complete block design (RCBD) with five replicates was used for data collection following Townsend \& Heuberger (1943) and Biswas et al. (1992) Each treatment had 100 leaflets (20 leaflets/replicate) which were examined to assess the disease severity as the percentage of infected area based on a 1-5 scale divised by Townsend \& Heuberger (1943) and Biswas et al. (1992) (Table 3, Fig. 2).

The powdery mildew disease severity was also assessed by scoring selected at random, on a scale of $1-5(1=1-10 \%, 2=11-15 \%, 3=16-25 \%, 4=25-50 \%$ and $5=>50 \%$ of leaf area infected with powdery mildew growth. The percent disease index (PDI) was calculated following Mckinney (1923) and the methods of Chiang et al. (2017) infection index.

$$
\mathrm{PDI}=\frac{\text { Sum of all individual ratings }}{\text { Total number of leaves observed }} \quad \mathrm{X} \quad \frac{100}{\text { Maximum disease grade }}
$$

The effectiveness of the treatments was calculated according to the following formula:

$$
\% \text { Efficiency }=\frac{\% \text { infection in the control }-\% \text { infection in the treatment }}{\% \text { infection in the control }} \times 100
$$

\section{Results}

The hyperparasitic fungus Ampelomyces spp. was isolated from primary infections of powdery mildew that appeared on the leaf surfaces of four species of hosts: Golovinomyces cichoraceanum, Podosphaera xanthii, Pseudoidium hortensiae and Golovinomyces cichoraceanum (Table 1). Colonies presented a brownish colour. Morphological characteristics were observed by light microscope and included pycnidia which varied in shape (ovoid and ellipsoid) depending on the host fungus, and conidia measuring average approximately 10.5 to $13.5 \mu \mathrm{m}$ in length $\mathrm{x} 2.5$ to $3.0 \mu \mathrm{m}$ in width. Scanning electron microscope (SEM) indicated that Ampelomyces spp. penetrated into powdery mildew mycelium (Fig. 1).

Table 1 Screening Ampelomyces spp. from powdery mildew hosts.

\begin{tabular}{llll}
\hline $\begin{array}{l}\text { Isolate } \\
\text { Name }\end{array}$ & Host plants $^{\text {a }}$ & Powdery mildew host fungus & Area of isolation \\
\hline AMP1-Ze & Zinnia elegans & $\begin{array}{l}\text { Podosphaeca fusca } \\
\text { (Mukhtar \& Arend 2017) }\end{array}$ & Mae-Sai, Chiang Rai \\
AMP2-Ac & Ageratum conyzoides & $\begin{array}{l}\text { Podosphaera xanthii } \\
\text { (Braun \& Cook 2012) }\end{array}$ & Mae-on, Chiang Mai \\
AMP3-Hg & Hydrangea sp. & $\begin{array}{l}\text { Pseudoidium hortensiae } \\
\text { (Meeboon \& Takamutsa 2015) } \\
\text { Golovinomyces cichoraceanum } \\
\text { (Braun \& Cook 2012) }\end{array}$ & Bhubing Palace, Chiang Mai \\
AMP4-Dl & Dahlia spp. & Bhubing Palace, Chiang Mai \\
\hline
\end{tabular}

${ }^{a}$ All specimens were deposited in the Mycological Herbarium in the Department of Entomology and Plant Pathology, Faculty of Agriculture, Chiang Mai University, Thailand. 

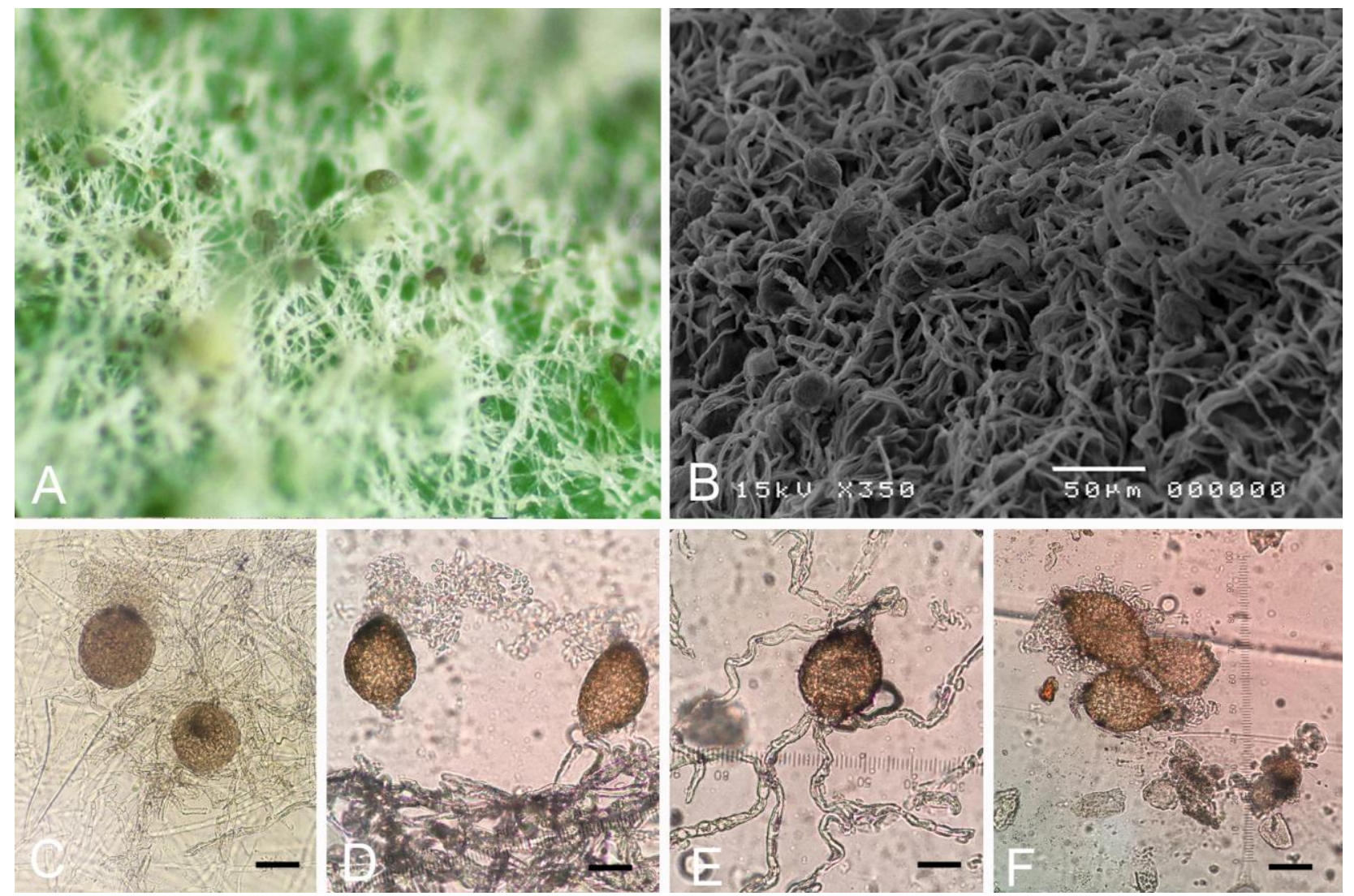

Fig. 1 - Ampelomyces spp. on powdery mildew. A Pycnidial hyperparasitism of powdery mildew on leaf surface. B Microscopic interactions between mycoparasites Ampelomyces and powdery mildew, SEM micrographs. C Pycnidia and conidia isolated from Golovinomyces cichoraceanum. D Pycnidia and conidia isolated from Podosphaera xanthii. E. Pycnidia and conidia isolated from Pseudoidium hortensiae. F Pycnidia and conidia isolated from Golovinomyces cichoraceanum Scale bars: $\mathrm{A}=10 \mu \mathrm{m}, \mathrm{B}=50 \mu \mathrm{m}, \mathrm{C}-\mathrm{F}=10 \mu \mathrm{m}$.

Table 2 Effect of biocompounds of Ampelomyces spp. on inhibition of Podosphaera pannosa conidial germination.

\begin{tabular}{lcccccc}
\hline \multirow{2}{*}{ Biocompounds } & \multicolumn{5}{c}{ Growth Inhibition $\mathbf{1}^{\mathbf{1 , 2}}(\boldsymbol{\%})$ at each concentration (ppm) } \\
\cline { 2 - 7 } & $\mathbf{1 0}$ & $\mathbf{5 0}$ & $\mathbf{1 0 0}$ & $\mathbf{5 0 0}$ & $\mathbf{1 , 0 0 0}$ & $\mathbf{L C} \mathbf{C}_{\mathbf{5 0}}(\mathbf{p p m})$ \\
\hline Ampelomyces sp. AMP1-Ze (EtOH) & $20^{\mathrm{d}}$ & $29^{\mathrm{d}}$ & $40^{\mathrm{c}}$ & $60^{\mathrm{b}}$ & $75^{\mathrm{a}}$ & 190.55 \\
Ampelomyces sp. AMP2-Ac (EtOH) & $15^{\mathrm{d}}$ & $39^{\mathrm{c}}$ & $65^{\mathrm{b}}$ & $71^{\mathrm{b}}$ & $84^{\mathrm{a}}$ & 91.20 \\
Ampelomyces sp. AMP3-Hg (EtOH) & $12^{\mathrm{e}}$ & $41^{\mathrm{d}}$ & $56^{\mathrm{c}}$ & $68^{\mathrm{b}}$ & $83^{\mathrm{a}}$ & 109.64 \\
Ampelomyces sp. AMP4-D1 (EtOH) & $21^{\mathrm{e}}$ & $35^{\mathrm{d}}$ & $52^{\mathrm{c}}$ & $67^{\mathrm{b}}$ & $78^{\mathrm{a}}$ & 112.20 \\
\hline
\end{tabular}

${ }^{1}$ Growth Inhibition (GI) = R1-R2/R1x100: R1 = Number of spores of the tested pathogen produced in the control $(0 \mathrm{ppm})$ and $\mathrm{R} 2=$ Number spores of the tested pathogen produced at each concentration.

${ }^{2}$ The same letters following means in each column indicate that they are not significantly different using Duncan's multiple range test.

Table 3 Effect of a biocompound on P. pannosa powdery mildew severity.

\begin{tabular}{|c|c|c|c|}
\hline \multirow{2}{*}{$\begin{array}{l}\text { Treatments } \\
\text { (application time) }^{\mathrm{a}}\end{array}$} & \multicolumn{3}{|c|}{ Powdery mildew severity reading level $1-5^{b}$} \\
\hline & First reading initial infection & Highest reading $4 \mathrm{wk}$ & Efficiency $\%^{/ 1}$ \\
\hline Control (non-treated) & $1.52^{\mathrm{a}}$ & $4.72^{\mathrm{a}}$ & - \\
\hline $\begin{array}{l}\text { Ampelomyces sp. AMP2-Ac } \\
(100 \mathrm{ppm})\end{array}$ & $1.66^{\mathrm{a}}$ & $2.58^{\mathrm{b}}$ & $45.33^{b}$ \\
\hline Carbendazim (10cc/20L) & $1.58^{\mathrm{a}}$ & $2.29^{\mathrm{c}}$ & $51.48^{\mathrm{a}}$ \\
\hline
\end{tabular}

${ }^{\mathrm{a}}$ Application times were weekly for $4 \mathrm{wk}$ after initial powdery mildew infection. 
${ }^{\mathrm{b}}$ Mean disease severity reading $(1=1-10 \%, 2=11-15 \%, 3=16-25 \%, 4=26-50 \%$ and $5=>50 \%$ of leaf area infected with powdery growth); means followed by the same letters in column are not significantly different (LSD; $P=0.05$ )

${ }^{1}$ The averages were calculated using data from 10 plants per each treatment (10 leaves/plant).

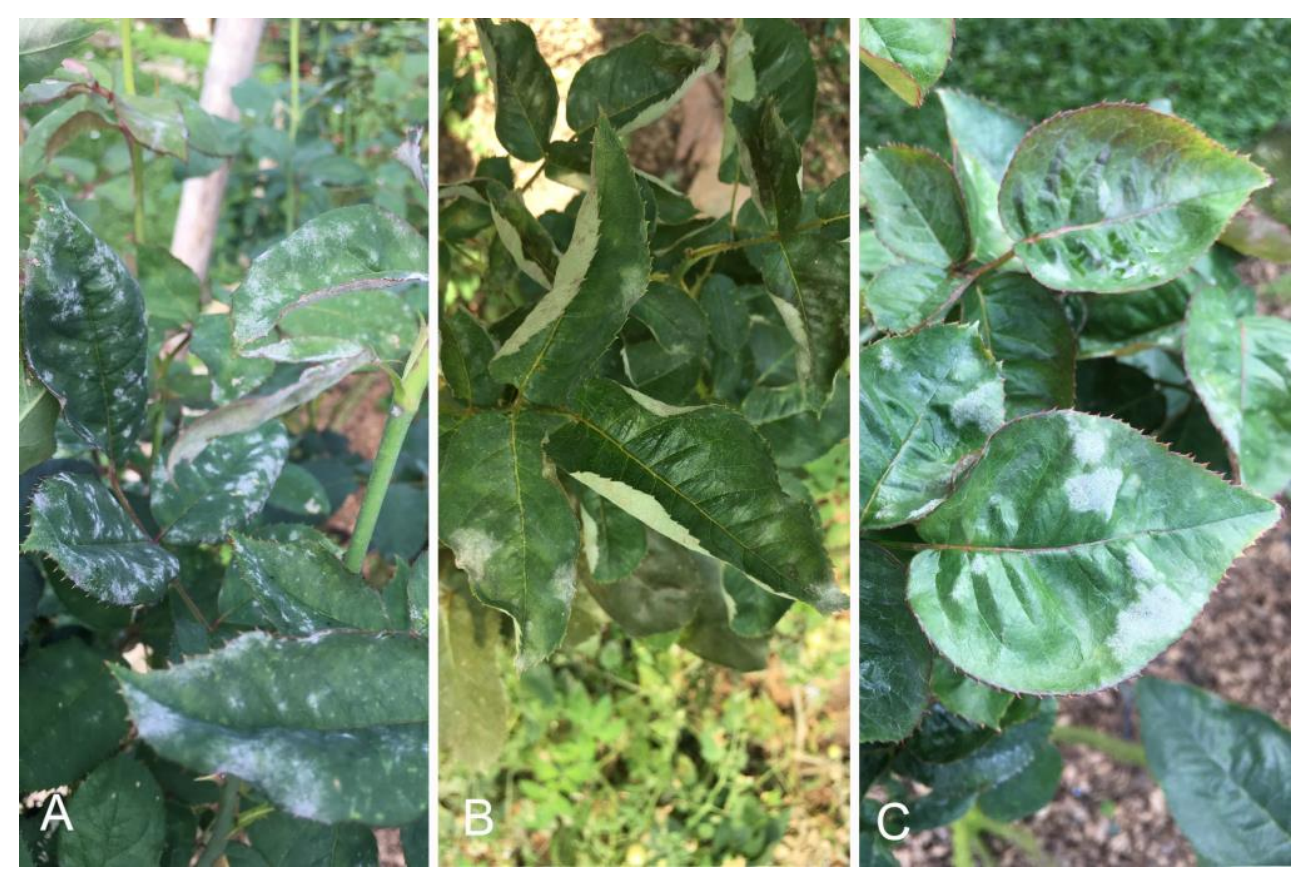

Fig. 2 - Disease severity in greenhouse experiment after spray application at 4 wk. A Control (nontreated). B Biocompound extract from Ampelomyces sp. C Chemical fungicide (carbendazim).

\section{Discussion}

The interaction of Ampelomyces spp. and powdery mildew in natural infections presents an opportunity most effective to control disease severity and develop a biological control product (Viterbo et al. 2007). The frequent application of a mycoparasite in the field or greenhouse was able to reduce powdery mildew severity (Diego et al. 2003). Successful infection of powdery mildew by Ampelomyces spp. occurs before or during rain events. This presents a difficulty for commercial plant management which can be overcome using spray equipment to create wet conditions (Stuart et al. 1995). Moreover, the relationship with its host fungi is also important factor (Claudia et al. 2005). So, the use of biocompounds in field or commercial-scale control is less problematic and could be developed as formulations. In this study the highest efficiency most effective biocompound was extracted from the Ampelomyces isolate infecting Ageratum conyzoides (AMP2-Ac) which compared favourably to the conventional fungicide (carbendazim $10 \mathrm{cc} / 20 \mathrm{~L}$ ) in reducing the severity of powdery mildew disease by $45.33 \%$ in greenhouse experiments. However, genetic diversity is needed to confirm the relationship between Ampelomyces mycoparasites and their hosts for control of powdery mildew on other host plants and to determine suitable timing for their use (Orsolya et al. 2005).

In conclusion, the results from this study indicated that biocompounds extracted from Ampelomyces spp. can inhibit powdery mildew conidial germination, and that the use of such biocontrol agents has potential for control of rose powdery mildew (Bélanger \& Labbé 1994). It appears that growers need to spray frequently to reduce the risk of powdery mildew disease.

\section{Acknowledgements}

The authors gratefully acknowledge the financial support provided by the Graduate School, Chiang Mai University. The authors wish to express their special thanks to Bhubing Palace for allowing the greenhouse experiment and Department of Entomology and Plant Pathology, Faculty of Agriculture, Chiang Mai University for providing the scientific instrument support. 
Furthermore, we thank Prof. Dr. Robert McGovern the anonymous individuals for helpful suggestion.

\section{References}

Amal HA, RuAngelie E, Victor W, Werner EGM et al. 2008 - Bioactive metabolites from the endophytic fungus Ampelomyces sp. isolated from medicinal plant Urospermum picroides. Phytochemistry 69, 1716-1725.

Biswas S, Teotia RS, Manal SK. 1992 - Some field observations on the severity of powdery mildew (Phyllactinia corylea) in mulberry. Indian Journal of Science 31, 67-69.

Braun U, Cook RTA. 2012 - Taxonomic Manual of the Erysiphales (Powdery Mildews). CBSKNAW Fungal Biodiversity Center, The Netherlands. IMA fungus (3)1, 35-36.

Bélanger R, Labbé C. 1994 - Commercial-scale control of rose powdery mildew with a fungal antagonist. Plant Disease 78(4), 420-424.

Carlo P, Ferdinando D, Paolo C, Maria L. 1997 - Effectiveness of antifungal compounds against rose powdery mildew (Sphaerotheca pannosa var. rosae) in glasshouses, Crop Protection 16, 251-256.

Chiang KS, Liu HI, Bock CH. 2017 - A discussion on disease severity index values. Part I: warning on inherent errors and suggestions to maximise accuracy. International journal of the Annals of Applied Biology 171, 139-154.

Claudia N, George N, Cort LA. 2005 - Host specialization of the mycoparasite Eudarluca Caricis and its evolutionary relationship to Ampelomyces. Mycological research 109(4), 421-428.

Cook RTA, Braun U. 2009 - Conidial germination patterns in powdery mildews. Mycological research 113, 616-636.

Cook R, Inman A, Billings C. 1997 - Identification and classification of powdery mildew anamorphs using light and scanning electron microscopy and host range data. Mycological research 101, 975-1002.

Dario A, Elisabetta P, Ilaria P. 2009 - Occurrence of Erysiphe necator Chasmothecia and Their Natatural Parasitism by Ampelomyces quisqualis. Phytopathology 99(6), 704-710.

Dario A, Krishna S, Guillem S, Carmela S, Ilaria P. 2017 - Production of Ampelomyces quisqualis conidia in submerged fermentation and improvements in the formulation for increased. Crop Protection 97, 135-144.

Diego R, Rivera ME, Francisco MC, Antonio DV, Alejandro P. 2003 - Effect of mycoparasitic fungi on the development of Sphaerotheca fusca in melon leaves. Mycological research. 107(1), 64-71.

Gu YH. 1998 - Liquid culture of Ampelomyces quisqualis, a mycoparasite for biological control of powdery mildews. Annals of the Phytopathological Society of Japan 64, 458-461.

$\mathrm{Gu}$ YH, Ko WH. 1997 - Water agarose medium for studying factors affecting germination of conidia of Ampelomyces quisqualis. Mycology Research Journal 101(4), 422-424.

Hirata K. 1942 - On the shape of the germ tubes of Erysiphaceae. Bull Chiba College of Horticulture 5, 34-39.

Ilaria P, Rosaly Z, Liat A, Mario B et al. 2008 - Integrating biocontrol agents in strawberry powdery mildew control strategies in high tunnel growing systems. Crop Protection 27, 622631.

Mckinney HH. 1923 - A new system of grading of plant diseases. Journal of Agricultural Research 26, 195-218.

Meeboon J, Takamatsu S. 2015 - Notes on powdery mildews (Erysiphales) in Japan: II. Erysiphe sect. Microsphaera: Mycoscience 56, 230-236.

Mukhtar I, Arend FP. 2017 - First Report of Podosphaera xanthii Causing Powdery Mildew on Ageratum conyzoides in China. Plant Disease 101(8), p.1553. 
Orsolya S, Levente K, John CR, Gábor MK et al. 2005 - Ampelomyces mycoparasites apple powdery mildew identified as distinct group based on single-stranded conformation polymorphism analysis of the rDNA ITS region. Mycological Research 109(4), 429-438.

Pathan AK, Gaskin RE. 2010 - Sample preparation for SEM of plant surfaces. Material Today 12(1), 32-43.

Paulitz TC, Bélanger RR. 2001 - Biological control in green house systems. Annual review of Phytopathology 39, 103-133.

Puzanova LA. 1991 - Distribution of hyperparasites from the genus Ampelomyces Ces. ex Schlecht. On the powdery mildew fungi in northern Caucasus and their importance in disease control. Mikol. Fitopatol.25, 438-442. Material Today 12, 32-43.

Stuart PF, David MG, Roger CP, Robert CS. 1995 - Partial control of grape powdery mildew by the mycoparasite Ampelomyces quisqualis. The American Phytopathological Society; Plant Disease 79(5), 483-490.

Townsend GR. Heuberger JW. 1943 - Methods for estimating losses caused by disease in fungicide experiments. Plant disease reporter 27, 340-343.

To-anun C, Takamatsu S. 2007 - Powdery mildews in genus Oidium subgenus Friboidium of Thailand: Integrated analyses of morphological and molecular characteristics. Proceedings of the International Conference on Integration of science and Technology for Sustainable Development (ICIST) "Biological Diversity, Food and Agricultural Technology". April 2627, 2007, KMITL, Bangkok. Thailand, 251-258.

Viterbo A, Inbar J, Hadar Y, Chet I. 2007 - Plant disease biocontrol and induced resistance Via fungal mycoparasites. Environmental and Microbial relationships, $2^{\text {nd }}$ Edition The Mycota IV.127-146. 